\title{
Krzysztof KOPEĆ
}

\section{POMORSKA KOLEJ METROPOLITALNA - FUNKCJONOWANIE I KIERUNKI ROZWOJU}

W artykule przedstawiono dotychczasowe funkcjonowanie Pomorskiej Kolei Metropolitalnej. Wskazano istotne osiagnięcia - zwłaszcza duża liczbę podróżnych $w$ połaczeniach regionalnych $-z$ Kartuzami i Kościerzyna, a także systematyczny wzrost liczby pasażerów we wszystkich relacjach. Wskazano też porażki - przede wszystkim niesatysfakcjonująca liczbę pasażerów w połaczeniach aglomeracyjnych. Jest ona efektem głównie zbyt małej częstotliwości kursowania pociagów, niedostosowania oferty dowozowej komunikacja publiczna do przystanków Pomorskiej Kolei Metropolitalnej oraz słabego skomunikowanie z pociagami Szybkiej Kolei Miejskiej na stacjach Gdynia Główna i Gdańsk Wrzeszcz. Pomorska Kolej Metropolitalna rozwija się - przykładem jest przede wszystkim uruchomienie 10 grudnia 2017 r. nowych przystanków Gdynia Karwiny oraz Gdynia Stadion. W planach sa kolejne inwestycje - w tym przede wszystkim budowa nowego przystanku Gdańsk Firoga, elektryfikacja Pomorskiej Kolei Metropolitalnej oraz modernizacja linii kolejowej nr 201, której odcinek pomiędzy Gdynia Gtówna a Kościerzyna jest częścia Pomorskiej Kolei Metropolitalnej. Natomiast kierunkami rozwoju Pomorskiej Kolei Metropolitalnej powinno być poza likwidacja wymienionych w artykule mankamentów, które ujawnito dotychczasowe funkcjonowanie, przede wszystkim przedlużenie linii z Kartuz do Sierakowic oraz wybudowanie peronu Pomorskiej Kolei Metropolitalnej w ramach przystanku Szybkiej Kolei Miejskiej Gdynia Wzgórze Św. Maksymiliana.

\section{WSTĘP}

Pomorska Kolej Metropolitalna jest dla aglomeracji gdańskiej przedsięwzięciem o wyjątkowym rozmiarze i znaczeniu. Wciąż też pozostaje szczególną inwestycja w skali Polski. Inwestycją działajaca od września 2015 r., ale wciąż podlegająca przemianom i rozbudowie. Stąd oceny jej dotychczasowego funkcjonowania oraz wyznaczanie kierunków rozwoju są szczególnie potrzebne.

Pomorska Kolej Metropolitalna była jednym spośród trzech projektów rozbudowy kolei o charakterze miejskim i aglomeracyjnym jakie zostały zrealizowane po 2010 r. w aglomeracji gdańskiej. Dwa pozostałe to wydłużenie linii Szybkiej Kolei Miejskiej na południe od stacji Gdańsk Główny do nowo wybudowanego przystanku Gdańsk Śródmieście oraz przywrócenie okazjonalnego kursowania pociagów SKM na linii kolejowej nr 249 pomiędzy Stacją Gdańsk Główny, a nowo wybudowanym przystankiem Gdańsk Stadion Expo [por. 9; $11 ; 15 ; 16 ; 18 ; 19]$. Były to największe inwestycje odkąd ukończono elektrowozownię SKM w Gdyni Cisowej, której budowa rozpoczęła się pod koniec 1975 r., a zakończyła dopiero w grudniu 1988 r. po wcześniejszym ograniczeniu rozmiarów przedsięwzięcia [por. $5 ; 6$; 37]. Dodatkowo w tym okresie udało się dobudować trzeci tor wzdłuż linii kolejowej nr 202 wydłużając linię kolejową nr 250 dedykowana SKM - najpierw na odcinku Gdynia Główna-Gdynia Chylonia, a następnie na odcinku Gdynia Chylonia-Rumia [6].

\section{FUNKCJONOWANIE POMORSKIEJ KOLEI METROPOLITALNEJ}

\subsection{Cele}

W studium wykonalności Pomorskiej Kolei Metropolitalnej główny cel projektu określono jako: podniesienie poziomu spójności społecznej i gospodarczej województwa pomorskiego, poprzez wdrożenie zintegrowanego z układem komunikacji publicznej Me- tropolii Trójmiejskiej systemu kolei regionalnej. Natomiast bezpośrednie cele projektu określono jako [34, s. 28-29]:

a) powiązanie ze sobą oraz $z$ centrami aglomeracji gdańskiej w Gdańsku i Gdyni docelowo dwóch portów lotniczych;

b) integracje funkcjonalno-przestrzenna poprzez udostępnienie szybkiego transportu kolejowego mieszkańcom zachodnich osiedli mieszkaniowych, zlokalizowanych na wzgórzach morenowych, takich jak: Witomino, Karwiny, Wielki Kack, Mały Kack, Fikakowo, Osowa, Piecki-Migowo jako alternatywy dla wykorzystania samochodów prywatnych;

c) zapewnienie lepszego dostępu do sieci kolejowych połączeń między aglomeracyjnych zarówno dla mieszkańców w/w osiedli, jak i pasażerów linii lotniczych;

d) umożliwienie mieszkańcom gmin położonych na wysoczyźnie kaszubskiej szybkiego i bezkolizyjnego dostępu do aglomeracji gdańskiej;

e) dążenie do maksymalnego zintegrowania podsystemów transportu zbiorowego i indywidualnego z niniejszym projektem, w tym uwzględnienie połączeń $z$ istniejącymi $\mathrm{i}$ projektowanymi systemami komunikacji tramwajowej.

Powyższe cele nie zostały w pełni zrealizowane. Pomorska Kolej Metropolitalna cechuje się wciąż dalece niewystarczajacą integracja z układem komunikacji publicznej aglomeracji gdańskiej. Poprawie wymaga też integracja $z$ transportem indywidualnym samochodowym i rowerowym. W efekcie wymienione czynniki wraz z niesatysfakcjonująca częstotliwością kursowania skutkują w dużym zakresie niezrealizowana zakładana integracja funkcjonalnoprzestrzenna zachodnich osiedli mieszkaniowych zlokalizowanych na wzgórzach morenowych oraz centralnej części Kaszub z jednej strony, a obszarem centralnym aglomeracji gdańskiej z drugiej strony.

\subsection{Przebieg}

Pierwsze prace zwiazane z realizacja projektu Pomorskiej Kolei Metropolitalnej podjęto 3 stycznia 2013 r. Były to rozbiórki budyn- 
ków zlokalizowanych na jej trasie. Natomiast 9 stycznia 2013 r. rozpoczęła się wycinka drzew stojących w pasie kolejowym. Po niespełna 2 latach i ośmiu miesiącach - 1 września 2015 r. rozpoczęło się regularne kursowanie pociagów pasażerskich Pomorskiej Kolei Metropolitalnej. Jeśli nie liczyć budowanej w latach 1983-2008 pierwszej linii metra w Warszawie długości 23,1 km, Pomorska Kolej Metropolitalna była najdłuższą nowo wybudowaną linią kolejową w Polsce od 1979 r., kiedy oddano do użytku Linię Hutniczo-Siarkową (od 2001 r. funkcjonująca pod nazwą Linia Hutnicza Szerokotorowa) długości 394,65 km [14]. Jej podstawowym celem są poprawa obsługi komunikacyjnej peryferyjnych dzielnic Gdańska i Gdyni, zdecydowanie lepsze skomunikowanie Trójmiasta z Portem Lotniczym Gdańsk im. Lecha Wałęsy oraz bezpośrednie połączenie kolejowe głównej części Kaszub (Kościerzyny i Kartuz) z Gdańskiem (tym samym odbudowano połączenie, które funkcjonowało w latach 1914-1945 w ramach linii Gdańsk Wrzeszcz-Stara Piła). Dwa pierwsze cele mają charakter aglomeracyjny, natomiast trzeci cel ma charakter regionalny. [15]:

Pomorska Kolej Metropolitalna składa się z trzech fragmentów

1. Odcinka biegnącego śladem linii kolejowej Gdańsk WrzeszczStara Piła, która została zniszczona w 1945 r., a następnie rozebrana. Odcinek ten o długości 9,8 km przebiega od stacji kolejowej Gdańsk Wrzeszcz, gdzie Pomorska Kolej Metropolitalna została włączona w linię kolejową nr 202 Gdańsk-Stargard (czyli w tzw. tory dalekobieżne) przez dzielnicę Strzyża, wschodni skraj osiedla Niedźwiednik, następnie Dolne Migowo, północny skraj osiedla Jasień i Kiełpinek. Dalej przechodzi pod obwodnicą Trójmiasta (na tym odcinku nosi ona nazwę al. Kazimierza Jagiellończyka), będącą częścią drogi ekspresowej S6. Po jej minięciu Pomorska Kolej Metropolitalna odchodzi w kierunku północnym od dawnego przebiegu linii kolejowej Gdańsk Wrzeszcz-Stara Piła.

2. Odcinka biegnącego nowym śladem kolejowym. Przebiega on przez Matarnię, Port Lotniczy Gdańsk im. Lecha Wałęsy, a w sąsiedztwie miejscowości Rębiechowo i Banino włącza się w linię kolejową nr 201 z Kościerzyny do Gdyni (precyzyjniej rzecz ujmując jest to linia Nowa Wieś Wielka-Gdynia Port Centralny). Główne połączenie dwutorowe zostało wyprowadzone w kierunku Gdyni, natomiast w kierunku Kartuz i Kościerzyny Pomorska Kolej Metropolitalna posiada jednotorową łącznicę długości 1,35 $\mathrm{km}$.

3. Odcinka linii kolejowej nr 201 będącego częścią Magistrali Węglowej. Odcinek ten przebiega przez Osowę, Wielki Kack, następnie biegnie granica pomiędzy gdyńskimi dzielnicami Karwiny i Mały Kack do Gdyni Głównej.

Pomorska Kolej Metropolitalna pomiędzy Gdańskiem Wrzeszczem a Gdańskiem Osową to linia kolejowa nr 248. Natomiast jednotorowe odgałęzienie od Gdańska Rębiechowa w kierunku Kartuz i Kościerzyny to linia kolejowa nr 253.

Aktualny schemat przebiegu Pomorskiej Kolei Metropolitalnej przedstawiony jest na rys. 1 . Nie obejmuje on obsługiwanych przez pociagi PKM linii kolejowej nr 201 na odcinku pomiędzy Rębiechowem a Kościerzyną oraz linii kolejowej nr 229 pomiędzy Glinczem a Kartuzami. Pierwsza z nich była wykorzystywana wcześniej przez pociagi regionalne w relacjach Gdynia Główna-Kościerzyna, natomiast na drugiej od 1994 r. nie prowadzono ruchu pociagów pasażerskich.

\subsection{Infrastruktura i tabor}

Realizacja Pomorskiej Kolei Metropolitalnej, mimo że w znacznej części poprowadzona była śladem linii kolejowej Gdańsk Wrzeszcz-Stara Piła, to wymagała wybudowania całej infrastruktury od podstaw. Stąd pozostałości wszystkich dotychczas zachowanych wiaduktów zostały wyburzone, a w ich miejsce powstały nowe obiekty. W sumie wybudowano 17 wiaduktów kolejowych (w tym najdłuższy - o długości 940 m, składający się z 25 przęseł, biegnacy wzdłuż gdańskiego lotniska), 5 wiaduktów drogowych, 4 kładki

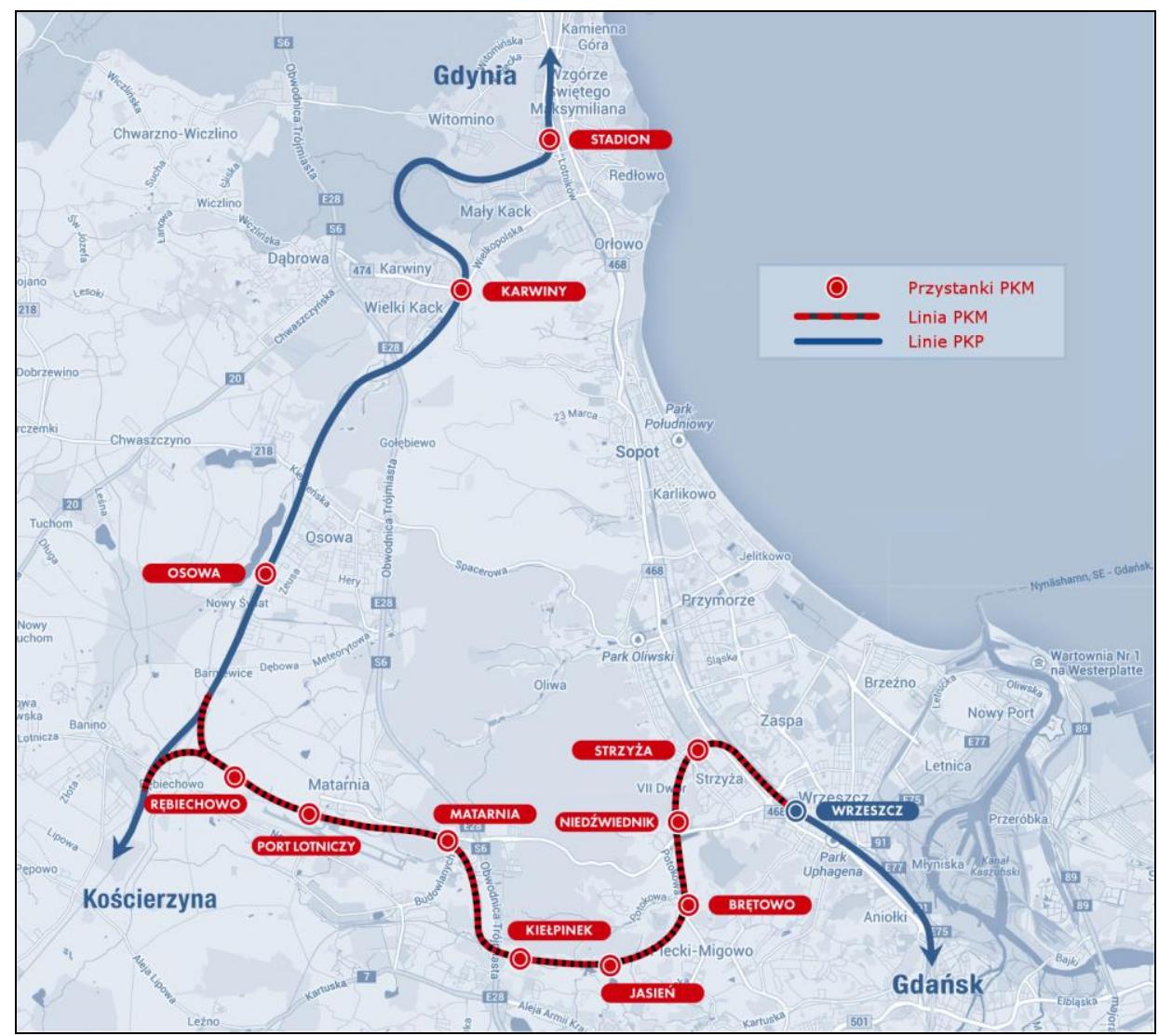

Rys. 1. Przebieg Pomorskiej Kolei Metropolitalnej [23]. 
dla pieszych, 4 przejścia pod torami oraz 11 przepustów i przejść dla zwierząt. Częścią inwestycji jest też Lokalne Centrum Sterowania w Matarni [15].

W ramach nowej linii kolejowej powstało, nie licząc dodatkowego peronu na stacji Gdańsk-Wrzeszcz, także 8 nowych przystanków. Ponadto w październiku 2013 r. marszałek województwa pomorskiego ogłosił decyzję o rozszerzeniu, realizowanego już projektu, o trzy dodatkowe przystanki dla pociagów Pomorskiej Kolei Metropolitalnej: Gdańsk Osowa, Gdynia Karwiny i Gdynia Stadion. Przy czym budowa dwóch z nich - Gdynia Karwiny i Gdynia Stadion rozpoczęła się jesienią 2016 r., natomiast ich włączenie do użytku nastapiło wraz z nowym rozkładem jazdy pociagów 10 grudnia 2017 r. Sa one zlokalizowane przy istniejącej wcześniej linii kolejowej nr 201 i mieszczą się w pasie kolejowym należącym do PKP PLK.

Zanim uruchomiono przystanki Gdynia Karwiny i Gdynia Stadion pociagi PKM zatrzymywały się na powstałej w 1930 r. podczas budowy magistrali węglowej stacji Gdynia Wielki Kack.

Przystanki PKM zostały kompleksowo opisane dla potrzeb osób niewidomych i słabowidzących. Ten element infrastruktury tworzą ścieżki dotykowe, pasy bezpieczeństwa i schematy dotykowe przystanków umieszczane przy wejściach na perony. Opisy w języku Braille'a znajdują się także na początkach poręczy schodów, a pasy naprowadzające osoby niewidome do wind prowadzą na opisane Braille'em przyciski, a nie - jak najczęściej się spotyka - na środek drzwi.

Na przystanku Gdynia Karwiny wybudowano czteroszynowy splot torowy. Wynika to z tego, że przystanek ten położony jest na łuku peronu. W efekcie pociagi z towarami ponadgabarytowymi, z ładunkiem z przekroczona skrajnią są kierowane na tor w bezpiecznej odległości od peronu. Natomiast pociagi osobowe poruszają się torem bliżej peronu. Splot ten jest jedynym tego typu w Polsce. (Podobny, ale trójszynowy, funkcjonuje w wielkopolskim Pleszewie. Na 4 km odcinku torów pomiędzy stacją Pleszew Waskotorowy a Pleszew Miasto poruszaja się osobowe pociagi wąskotorowe standardu $750 \mathrm{~mm}$, oraz normalnotorowe towarowe - $1435 \mathrm{~mm}$ ).

Wzdłuż linii PKM wybudowano 6 masztów GSM-R, będących częścią systemu sterowania ruchem ERTMS, odpowiadającego za automatyzację nadzoru nad prowadzeniem ruchu pociagów. Cztery z nich mają wysokość $32,5 \mathrm{~m}$, najniższy - 22,5 m - stoi w okolicach lotniska, a najwyższy - $48 \mathrm{~m}$ - w okolicach dawnego poligonu na Jasieniu. Wybrane lokalizacje 6 masztów GSM-R umożliwiaja zalogowanie pociagu do systemu zarządzania ruchem kolejowym przy maksymalnej dozwolonej prędkości na danym odcinku linii [31].

Pomorska Kolej Metropolitalna obsługiwana jest trakcją spalinowa. Operatorem przewozów w jej ramach jest PKP Szybka Kolej Miejska w Trójmieście Sp. z 0.o. Wykorzystuje ona przede wszystkim siedem trójczłonowych spalinowych zespołów trakcyjnych Pesa 219M oznaczonych jako SA136 oraz trzy dwuczłonowe Pesa 218Mc oznaczone jako SA133. Zostały one zakupione przez Urząd Marszałkowski Województwa Pomorskiego specjalnie do obsługi PKM. Jednak część kursów wykonywana jest innym taborem. Odbywa się to zarówno pozaplanowo w przypadku awarii ww. zespołów trakcyjnych, jak i planowo - zwłaszcza w relacjach do Kościerzyny.

\subsection{Przewozy}

Na rys. 2. przedstawiono liczbę pasażerów przewieziona pociagami uruchamianymi w ramach Pomorskiej Kolei Metropolitalnej od września 2015 r. do grudnia 2017 r. Były to następujące relacje (W nawiasach umieszczono stacje które nie były obsługiwane wszystkimi kursami.):

- Gdańsk Wrzeszcz-Gdańsk Osowa-(Gdynia Główna);

- (Gdańsk Główny)-Gdańsk Wrzeszcz-Kartuzy;

- (Gdynia Główna-Sopot)-Gdańsk Wrzeszcz-Kartuzy;

- Gdynia Główna-Sopot-Gdańsk Wrzeszcz-Kościerzyna;

- Gdynia Główna-Gdańsk Osowa-Kościerzyna.

Podstawową cechą jest zaznaczający się trend wzrostowy od 130-150 tys. przewiezionych pasażerów miesięcznie w początku funkcjonowania PKM do 270-290 tys. przewiezionych pasażerów miesięcznie w czwartym kwartale 2017 r. Przy czym dwie przyczyny modyfikują ujemnie ten trend:

1. Wyraźnie odznaczający się na rys. 2. gwałtowny spadek liczby podróżnych w lipcu i sierpniu 2016 r. spowodowany został długotrwałymi i intensywnymi opadami deszczu w dniach 14-15 lipca 2016 r., które doprowadziły do uszkodzenia linii kolejowych nr 248 i 253 należących do PKM, a także linii 201 należącej do PKP PLK na odcinku pomiędzy stacjami Gdańsk Osowa a Gdynia Główna. Ze względu na bezpieczeństwo pa-

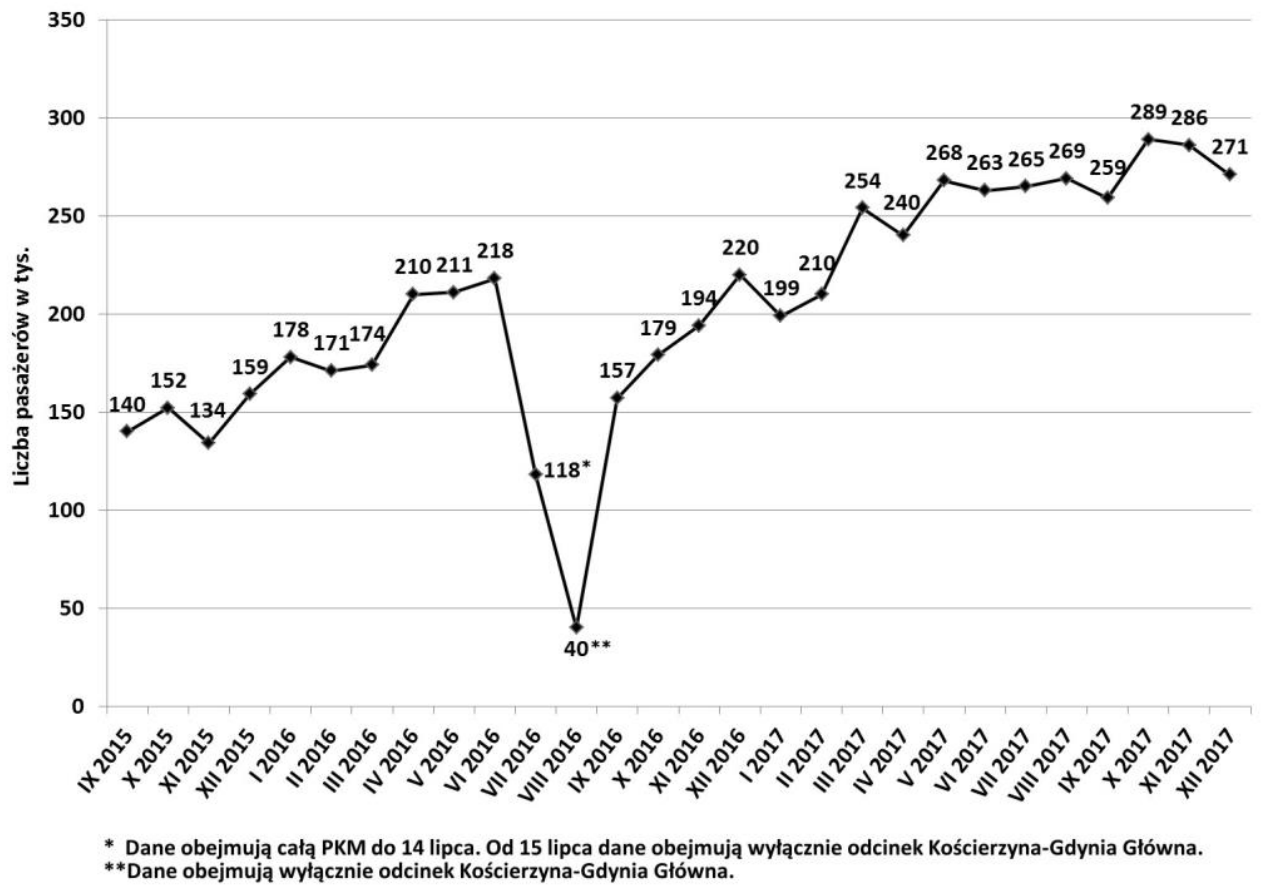

Rys. 2. Liczba pasażerów przewieziona pociagami Pomorskiej Kolei Metropolitalnej od września 2015 r. do grudnia 2017 r. 
sażerów w dniu 14 lipca 2016 r. o godz. 21.15 zostały wprowadzone ograniczenia prędkości pociagów PKM, a o godz. 23.11 został całkowicie wstrzymany ruch pociagów na linii PKM od stacji Gdańsk Wrzeszcz do stacji Gdańsk Osowa. Po dokonaniu napraw oddano do użytku 19 lipca linie nr 253 oraz 248 na odcinku pomiędzy przystankiem Gdańsk Port Lotniczy i linią 201 łącząca Gdynię z Kościerzyna, co umożliwiło uruchomienie pociagów na trasie Kartuzy-Gdańsk Port Lotniczy. Natomiast pozostała część PKM oddano do użytku 4 września, przy czym na odcinku Gdańsk Brętowo-Gdańsk Strzyża uruchomiono tylko jeden tor (nr 1). Wciąż zamknięty pozostawał też jeden tor (nr 101) na szlaku Gdańsk Osowa-Gdynia Główna. W efekcie liczba przewiezionych pasażerów w lipcu i sierpniu 2016 r. jest znacząco niższa. Ponadto dane z tych miesięcy przedstawione na rys. 2. nie obejmują części ruchu - zwłaszcza autobusowej komunikacji zastępczej. Natomiast we wrześniu 2016 r. ruch na PKM nie był prowadzony jeszcze w pełnym zakresie.

2. Od maja 2016 r., a następnie we wrześniu 2016 r. i w 2017 r. następowało zmniejszenie liczby połączeń na odcinku aglomeracyjnym PKM. Było to spowodowane niesatysfakcjonująca liczbą podróżnych na tej relacji względem pierwotnie uruchamianej liczby połączeń. Skutkowało to mniejszą dynamika wzrostu liczby podróżnych niż ta, która miała miejsce do kwietnia $2016 \mathrm{r}$.

W 2017 r. na wszystkich trasach kolejowych obsługiwanych przez PKP SKM w Trójmieście w ramach projektu Pomorskiej Kolei Metropolitalnej przewieziono 3 073,2 tys. pasażerów. W 2018 r. trend wzrostowy uległ wzmocnieniu - na co m.in. wpływ miało uruchomienie 10 grudnia 2017 r. nowych przystanków Gdynia Karwiny i Gdynia Stadion. Według danych Pomorskiej Kolei Metropolitalnej S.A. w marcu 2018 r. przewieziono 324,4 tys. pasażerów - to jest 0 $12,2 \%$ pasażerów więcej niż w najlepszym miesiącu 2017 r. - październiku.

Wspomniany wzrost liczby pasażerów w efekcie uruchomienia przystanków Gdynia Karwiny i Gdynia Stadion widać na rys. 3. O ile w listopadzie 2017 r. stacja Gdynia Wielki Kack obsłużyła 3,2 tys. pasażerów, to w grudniu 2017 r. stacja Gdynia Wielki Kack (funkcjonująca do 9 grudnia) oraz przystanki Gdynia Karwiny i Gdynia Stadion (funkcjonujace od 10 grudnia) obsłużyły w sumie już 4,7 tys. pasażerów, a w styczniu 2018 r. przystanki Gdynia Karwiny i Gdynia Stadion obsłużyły aż 9,0 tys. pasażerów.

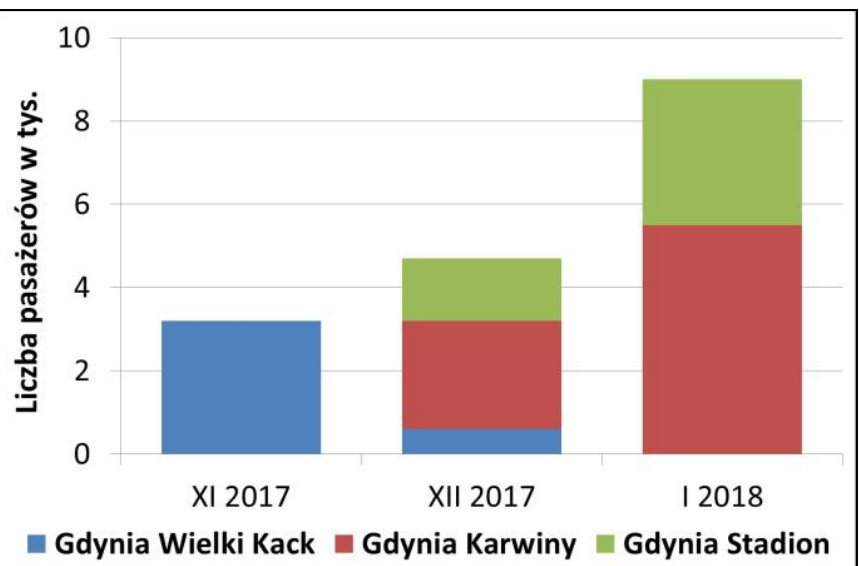

Rys. 3. Liczba pasażerów korzystających ze stacji Gdynia Wielki Kack oraz przystanków Gdynia Karwiny i Gdynia Stadion w listopadzie 2017 r., grudniu 2017 r. oraz styczniu 2018 r.

Nowe przystanki Gdynia Karwiny i Gdynia Stadion stanowia uzupełnienie oferty przewozowej komunikacją publiczna. Widać to m.in. po liczbie pasażerów obsługiwanych przez pociagi PKM na przystanku Gdynia Główna. W grudniu 2017 r. było ich 16,5 tys. a w styczniu 2018 r. 18,5 tys.

Interesujące jest to, że przystanki Gdynia Karwiny i Gdynia Stadion posiadają odmienne charakterystyki przepływów pasażerów. Według danych Pomorskiej Kolei Metropolitalnej S.A. większość ruchu w porannym szczycie przewozowym odbywa się z przystanku Gdynia Karwiny w kierunku Gdańska oraz z Gdańska na przystanek Gdynia Stadion. W popołudniowym szczycie przewozowym sytuacja ulega odwróceniu - większość ruchu odbywa się z Gdańska na przystanek Gdynia Karwiny oraz z przystanku Gdynia Stadion w kierunku Gdańska. Jest to spowodowane tym, że w okolicy przystanku Gdynia Karwiny znajduje się duże osiedle, pełniące funkcję niemalże wyłącznie mieszkaniowa, dotychczas bardzo słabo skomunikowane z zachodnimi dzielnicami Gdańska, strefa podmiejską zlokalizowaną na zachód od nich i słabo skomunikowane z gdańskimi dzielnicami Wrzeszcz, Zaspa i Przymorze. Natomiast w bezpośrednim sąsiedztwie przystanku Gdynia Stadion znajduje się kompleks biurowców dotychczas słabo skomunikowany z zachodnimi dzielnicami Gdańska i strefą podmiejską zlokalizowaną na zachód od nich.

Obciążenie pod względem wymiany pasażerskiej poszczególnych stacji i przystanków obsługiwanych pociagami PKM pokazuja wykonane przez Pomorskie Biuro Planowania Regionalnego pomiary natężenia ruchu pasażerskiego na liniach kolejowych obsługiwanych przez PKP Szybka Kolej Miejska w Trójmieście Sp. z 0.0. Wykonano je w 2016 i 2017 r. w miesiącach październiku i listopadzie. Zliczanie pasażerów wysiadających z pociagów i wsiadających do pociagów prowadzono przez 8 godz. w ciagu doby - pomiędzy 6.00 a 9.00 oraz pomiędzy 14.00 a 19.00 . Wyniki tego badania przedstawiono w tab. 1. Przy czym w przypadku dwóch stacji Gdańsk Wrzeszcz i Gdynia Główna przedstawiony wynik obejmuje także pasażerów wsiadających i wysiadających z pociąów szybkiej kolei miejskiej.

Z przeprowadzonego pomiaru w 2017 r. wynika, że spośród stacji i przystanków obsługiwanych wyłacznie przez pociagi PKM, największy przyrost liczby pasażerów względem pomiaru w 2016 r. zarówno w liczbach bezwzględnych jak i procentowo wystapił na przystanku Gdańsk Strzyża - o 828 co odpowiada wzrostowi o $122 \%$, następnie na przystanku Gdańsk Jasień - o 639 co odpowiada wzrostowi o 105\% oraz na stacji Kartuzy - o 524 co odpowiada wzrostowi o 104\%.

Zmniejszenie się liczby pasażerów w przeprowadzonym pomiarze w 2017 r. względem pomiaru w 2016 r. odnotowano wyłącznie na trzech stacjach i przystankach. Przy czym zmiana na przystanku Wieżyca z 60 na 57 oraz zmiana na przystanku Sławki z 34 na 31 biorąc pod uwage przyjęta metodologię pomiaru jest nieistotna. Natomiast niepokojące jest zmniejszenie się liczby pasażerów na stacji Gdańsk Osowa o 136 co odpowiada spadkowi o 15\%. Świadczy to o spadku konkurencyjności PKM w podróżach w porannym i popołudniowym szczycie przewozowym dla mieszkańców dzielnicy Osowa oraz sąsiadującej z nią strefy podmiejskiej.

Na podstawie uzyskanych wyników pomiaru wykonanego przez Pomorskie Biuro Planowania Regionalnego w październiku i listopadzie 2017 r. przedstawiono na rys. 4. zestawienie stacji i przystanków obsługiwanych wyłącznie przez pociagi PKM od tych najbardziej obciążonych pod względem wymiany pasażerów, po te najmniej obciażone pod względem wymiany pasażerów. W trakcie porannego (6.00-9.00) i popołudniowego (14.00-19.00.) szczytu przewozowego najwięcej pasażerów odnotowano na stacjach i przystankach Gdańsk Strzyża, Gdańsk Jasień, Kartuzy, Gdańsk Port Lotniczy oraz Gdańsk Kiełpinek, natomiast najmniej odnotowano na przystankach Wieżyca, Skorzewo, Krzeszna, Sławki oraz Babi Dół. Na podstawie analizy danych Pomorskiej Kolei Metropoli- 
talnej S.A. można dodać, że jeśliby uzupełnić zestawienie o stację Gdynia Główna, to znalazłaby się ona w czołówce, natomiast stacja Gdańsk Wrzeszcz znalazłaby się na pierwszym miejscu.

Tab. 1. Liczba pasażerów obsługiwana na stacjach i przystankach kolejowych Pomorskiej Kolei Metropolitalnej w 2016 i 2017 r. w trakcie 8 godzinnej próby (pomiędzy 6.00 a 9.00 oraz pomiędzy

14.00 a 19.00) [38]

\begin{tabular}{|c|c|c|c|c|}
\hline \multirow{2}{*}{ Przystanek } & 2016 & 2017 & \multicolumn{2}{|c|}{ Różnica } \\
\hline & [pas/8 godz] & [pas/8 godz] & [pas/8 godz] & [\%] \\
\hline Gdańsk Wrzeszcz ${ }^{*}$ & 11724 & 14968 & 3244 & $28 \%$ \\
\hline Gdańsk Strzyża & 676 & 1504 & 828 & $122 \%$ \\
\hline Gdańsk Niedźwiednik & 157 & 288 & 131 & $83 \%$ \\
\hline Gdańsk Brętowo & 282 & 401 & 119 & $42 \%$ \\
\hline Gdańsk Jasień & 609 & 1248 & 639 & $105 \%$ \\
\hline Gdańsk Kiełpinek & 550 & 985 & 435 & $79 \%$ \\
\hline Gdańsk Matarnia & 211 & 376 & 165 & $78 \%$ \\
\hline Gdańsk Port Lotniczy & 690 & 988 & 298 & $43 \%$ \\
\hline Gdańsk Rębiechowo & 336 & 664 & 328 & $98 \%$ \\
\hline Rębiechowo & 146 & 178 & 32 & $22 \%$ \\
\hline Pępowo Kartuskie & 134 & 215 & 81 & $60 \%$ \\
\hline Żukowo Wschodnie & 250 & 492 & 242 & $97 \%$ \\
\hline Żukowo & 375 & 480 & 105 & $28 \%$ \\
\hline Borkowo & 201 & 318 & 117 & $58 \%$ \\
\hline Dzierżążno & 97 & 189 & 92 & $95 \%$ \\
\hline Kartuzy & 505 & 1029 & 524 & $104 \%$ \\
\hline Gdynia Główna* & 12945 & 13846 & 901 & $7 \%$ \\
\hline Gdynia Wielki Kack & 201 & 233 & 32 & $16 \%$ \\
\hline Gdańsk Osowa & 918 & 782 & -136 & $-15 \%$ \\
\hline Babi Dół & 11 & 12 & 1 & $9 \%$ \\
\hline Kiełpino Kartuskie & 110 & 158 & 48 & $44 \%$ \\
\hline Somonino & 118 & 212 & 94 & $80 \%$ \\
\hline Sławki & 34 & 31 & -3 & $-9 \%$ \\
\hline Wieżyca & 60 & 57 & -3 & $-5 \%$ \\
\hline Krzeszna & 29 & 52 & 23 & $79 \%$ \\
\hline Gołubie Kaszubskie & 146 & 194 & 48 & $33 \%$ \\
\hline Skorzewo & 39 & 54 & 15 & $38 \%$ \\
\hline Kościerzyna & 369 & 374 & 5 & $1 \%$ \\
\hline
\end{tabular}

*Dane dla stacji Gdańsk Wrzeszcz i Gdynia Główna obejmuja zarówno pasażerów korzystających z pociagów PKM jak i SKM.

Efektem pomiaru wykonanego przez Pomorskie Biuro Planowania Regionalnego w 2017 r. jest też kartogram natężenia ruchu pasażerskiego w pociagach PKM w dobie dnia powszedniego. Obejmuje on więc także przewozy prowadzone tymi pociagami na linii Gdańsk Główny-Gdańsk Wrzeszcz-Sopot-Gdynia Główna. Kartogram zamieszczony jest na rys. 5. Potwierdza on, że największe natężenie ruchu pasażerskiego występuje na podstawowej części Pomorskiej Kolei Metropolitalnej, a więc na linii Gdańsk Wrzeszcz-Gdańsk Rębiechowo. Przy tym bardzo duże natężenie ruchu pasażerskiego występuje też na jednotorowym fragmencie linii kolejowej nr 201 Rębiechowo-Glincz - a więc od włączenia się w nią linii PKM poprzez linię kolejową nr 253 do rozdzielenia ruchu w kierunku Kartuz poprzez linię kolejową nr 229.

\section{KIERUNKI ROZWOJU POMORSKIEJ KOLEI METROPOLITALNEJ}

\subsection{Przesłanki rozwoju}

Uruchomienie w 2015 r. Pomorskiej Kolei Metropolitalnej w zasadzie od razu zmieniło dotychczas niemalże statyczny obraz pasażerskiej kolei aglomeracyjnej i regionalnej Pomorza Gdańskiego [por. 2]. Chociaż Pomorska Kolej Metropolitalna notuje systematyczny wzrost liczby pasażerów, to jednak podkreślić należy, że oczekiwania z nią związane były większe. Prognozowano, że w pierwszym roku funkcjonowania PKM przewozy sięgną wartości od
4976 tys. do 6230 tys. pasażerów [7]. Natomiast w 2018 r. wciąż jest ona daleka osiagnięciu takich wyników. Jest tak mimo tego, że uwarunkowania funkcjonowania PKM i w efekcie możliwość stworzenia za jej pomoca atrakcyjnej oferty przewozowej powinny jednoznacznie skazywać ją na sukces.

Kolej aglomeracyjna jaką jest Pomorska Kolej Metropolitalna jest szczególnie efektywna w obsłudze dużych zespołów miejskich i ich otoczenia [por. $1 ; 20 ; 33 ; 35]$. W tym w szczególności portów lotniczych [por. 21]. Idealnie wpisuje się też w aktualne poglądy na kształtowanie komunikacji na obszarach metropolii [por. 10]. Jest elementem zrównoważonych systemów transportowych [por. 4; 14; 25]. Ponadto kolej aglomeracyjna może być elementem takiego kształtowania komunikacji, by zarówno stanowić odpowiedź na oczekiwanie przez mieszkańców podnoszenia jakości życia, jak i ową wyższą jakość życia kreować [por. 12, 36]. Dodatkowo kształtuje ona oczekiwane zachowania komunikacyjne [por. 22]. Kolej aglomeracyjna tworzy lepsze warunki dla rozwoju gospodarczego aglomeracji i regionu [por. 30]. Jest też elementem bardzo istotnej usługi publicznej - $\mathrm{w}$ efekcie skupia zainteresowanie zarówno mieszkańców, jak i władz samorządowych [por. 8; 17]. Docelowo PKM wpisuje się we wzrost znaczenia elektromobilności w transporcie zbiorowym [por. 27; 28]. Jeżeli weźmiemy pod uwagę aspekt regionalny oraz lokalny powstania i funkcjonowania Pomorskiej Kolei Metropolitalnej, to możemy wskazać, że jest ona częścią złożonego systemu programowania rozwoju regionalnego [por. 32]. Istotne jest też to, że silnie wpływa na kształtowanie struktury przestrzenno-funkcjonalnej w swoim sasiedztwie [por. 29].

\subsection{Rozwój infrastruktury}

Elementy rozwoju infrastruktury Pomorskiej Kolei Metropolitalnej zaczynając od najistotniejszych to:

1. Budowa drugiego toru na odcinku Gdańsk OsowaKościerzyna, budowa trzeciego toru na odcinku Gdynia Główna-Gdańsk Osowa oraz modernizacja linii kolejowej nr 201.

2. Odbudowa odcinka Kartuzy-Sierakowice linii kolejowej nr 229.

3. Budowa przystanku PKM Gdynia Wzgórze Św. Maksymiliana.

4. Przedłużenie linii PKM do północnych dzielnic Gdyni - Pogórza, Obłuża i Oksywia

5. Budowa łącznicy umożliwiającej połączenie linii kolejowych $\mathrm{nr}$ 214 (Somonino-Kartuzy) i 229 (odcinek Glincz-Kartuzy) w taki sposób, że dla relacji Somonino-Kartuzy-Glincz (i odwrotnie) nie będzie zachodzić potrzeba zmiany kierunku jazdy, a także ewentualna dobudowa drugiego toru dla wymienionych linii.

6. Budowa przystanku PKM Gdańsk Firoga.

7. Elektryfikacja linii kolejowych obsługiwanych pociagami Pomorskiej Kolei Metropolitalnej.

Część wymienionych inwestycji zostanie w najbliższych latach zrealizowana. Prowadzony jest projekt PKP PLK pt. „Prace na alternatywnym ciagu transportowym Bydgoszcz-Trójmiasto, Etap I”. W jego efekcie do 2023 r. maja zostać wykonane elementy wymienione w punktach 1, 5 oraz $7 \mathrm{w}$ zakresie linii zarządzanych przez PKP PLK. Natomiast projekt Pomorskiej Kolei Metropolitalnej S.A. pt. „Pomorska Kolej Metropolitalna Etap I - rewitalizacja „Kolei Kokoszkowskiej” Faza III - elektryfikacja linii kolejowych nr 248 i 253 wraz z budowa przystanku Gdańsk Firoga" ma zapewnić realizacje punktów 6 oraz 7 w zakresie linii zarządzanych przez PKM. Pierwszy z wymienionych projektów jest od września 2017 r. w fazie opracowywania dokumentacji projektowej inwestycji, natomiast drugi projekt w marcu 2018 r. otrzymał dofinansowanie Unii Europejskiej w wysokości 85\% z Programu Operacyjnego Infrastruktura i Środowisko 2014-2020. 


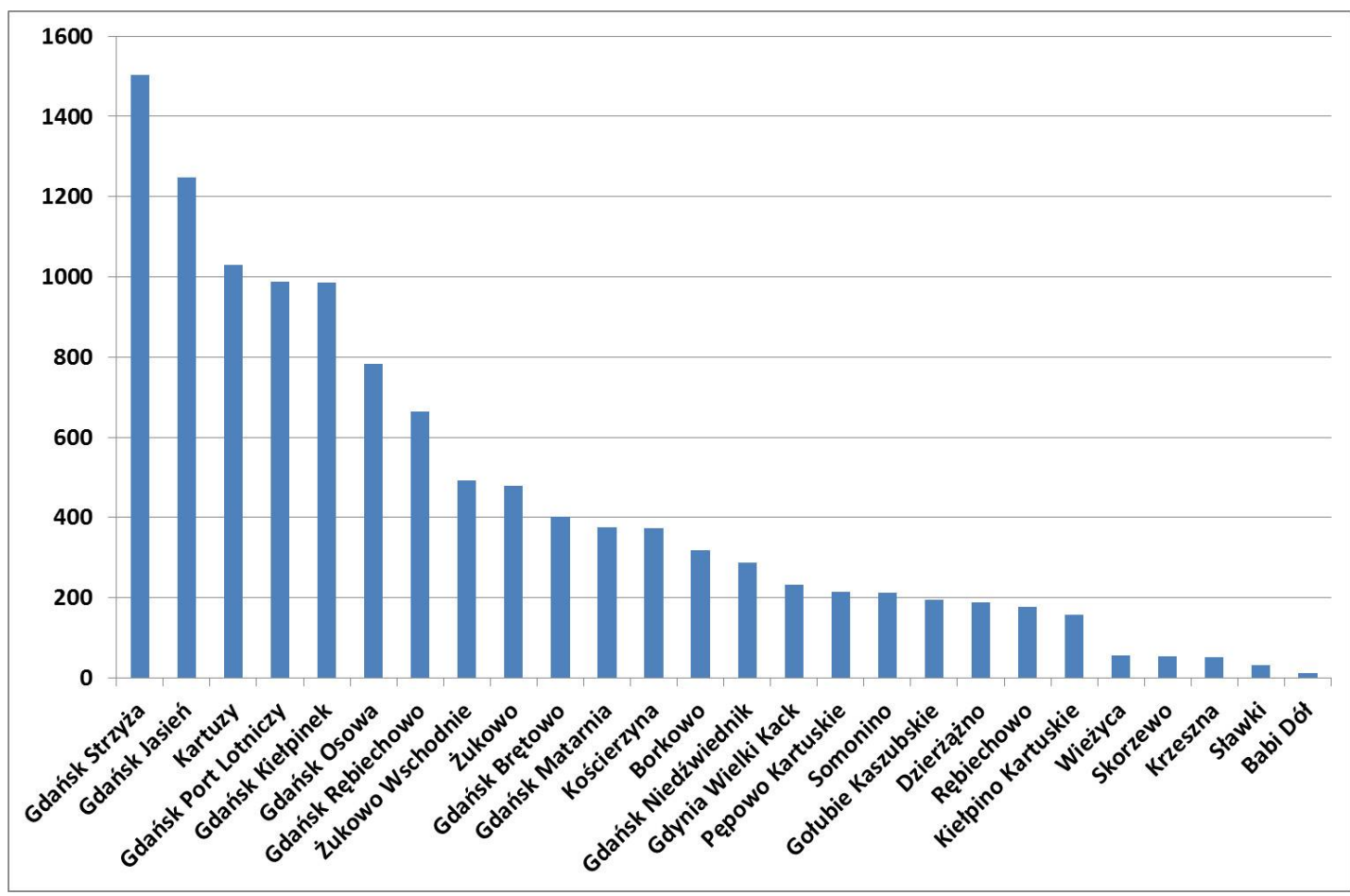

Rys. 4. Wielkości wymiany pasażerów na stacjach i przystankach obsługiwanych wyłącznie przez pociagi PKM w 2017 r. [38]

W planach pozostaje realizacja punktu 2. Co do jego zasadności nie ma istotnych zastrzeżeń. Można się więc spodziewać, że włączenie Sierakowic do PKM nastapi w najbliższych latach.

Odmienna sytuacje jest z realizacja punktów 3 i 4. Chociaż każdy z nich ma bardzo duże znaczenie, to nie są podejmowane aktualnie żadne działania aby inwestycje te zrealizować. Dzieje się tak mimo tego, że zarówno budowa przystanku Gdynia Wzgórze Św. Maksymiliana jak i przedłużenie linii PKM do północnych dzielnic Gdyni były w zasadzie od samego początku częścią idei Pomorskiej Kolei Metropolitalnej [14; 16].

\subsection{Rozwój organizacyjny}

O ile elementy rozwoju infrastruktury Pomorskiej Kolei Metropolitalnej można stosunkowo łatwo uszeregować zaczynając od najistotniejszych, to $z$ elementami rozwoju organizacyjnego jest znacznie trudniej. Składaja się one $z$ wielu, niekiedy drobnych zmian, które powinny być wdrażane równolegle i dodatkowo powinny podlegać monitoringowi oraz korektom. Tak więc zbiór elementów rozwoju organizacyjnego bez wskazania tych, które powinny być zrealizowane w pierwszej kolejności, przedstawia się następujaco:

a) skomunikowanie środków komunikacji publicznej z pociagami PKM;

b) zintegrowanie środków komunikacji publicznej z pociagami PKM;

c) zintegrowanie środków komunikacji indywidualnej z pociagami PKM;

d) zwiększenie prędkości handlowej pociagów PKM;

e) zwiększenie częstotliwości kursowania pociagów PKM;

f) zintegrowanie biletowe z pozostałymi systemami komunikacji publicznej w aglomeracji;

g) zmniejszenie kosztu przejazdu pociagiem PKM i pozostałymi środkami komunikacji publicznej w aglomeracji ponoszonego przez pasażera.

W zakresie każdego z wyżej wymienionych elementów rozwoju organizacyjnego Pomorskiej Kolei Metropolitalnej jest dużo do zrobienia. Wciąż na niezadowalającym poziomie występuje skomunikowanie innych środków komunikacji z pociagami PKM. Dotyczy to nawet pociagów SKM na stacji Gdańsk Wrzeszcz - a przecież to właśnie one są naturalnym środkiem kontynuacji podróży dla pasażerów PKM. Od uruchomienia PKM w wielu sytuacjach nie skorygowano tras komunikacji publicznej. W efekcie znaczna część przystanków PKM funkcjonuje w pewnej izolacji od pozostałej komunikacji publicznej. Niedostatecznie realizowana jest idea park and ride/park and rail oraz bike and ride/bike and rail [por. 13]. Na szczególnie wiele trudności w korzystaniu z PKM natrafiaja zwłaszcza rowerzyści. Jest tak mimo tego, że w Trójmieście, zwłaszcza w Gdańsku, ruch rowerowy jest wspierany od wielu lat [por. 3; 12]. Poprawie powinna też ulec prędkość handlowa oraz częstotliwość kursowania pociagów. W ostatnim aspekcie na odcinku aglomeracyjnym odnotowano istotny regres. Nadal też brakuje integracji biletowej z pozostałymi systemami komunikacji publicznej w aglomeracji, a nawet sama taryfa PKM/SKM jest dosyć skomplikowana [por. 26]. Wreszcie koszt przejazdu PKM i pozostałymi środkami komunikacji publicznej w aglomeracji powinien być wyraźnie konkurencyjny względem przejazdu samochodem, a tak $w$ wielu sytuacjach nie jest.

\section{PODSUMOWANIE}

Jeżeli wziąć pod uwagę obecne uwarunkowania procesu metropolizacji w aglomeracji gdańskiej to jako główne kierunki rozwoju systemu transportowego można określić: poprawę zewnętrznej dostępności transportowej aglomeracji, wzmacnianie wewnatrzregionalnych powiazań transportowych aglomeracji poprawiających jej spójność przestrzenną, kształtowanie warunków rozwoju sprawnego i efektywnego transportu zbiorowego oraz usprawnianie powiązań węzłów multimodalnych z infrastrukturą dostępności zewnętrznej [24]. We wszystkie te kierunki rozwoju wpisuje się Pomorska Kolej Metropolitalna.

Powstanie Pomorskiej Kolei Metropolitalnej jest znaczacym osiagnięciem. Niemniej jednak jej funkcjonowanie wymaga istotnych korekt i uzupetnień. Sa one konieczne do tego by PKM przynosiła oczekiwane korzyści, a poniesione nakłady można byłoby w pełni uznać za właściwie wydatkowane. 


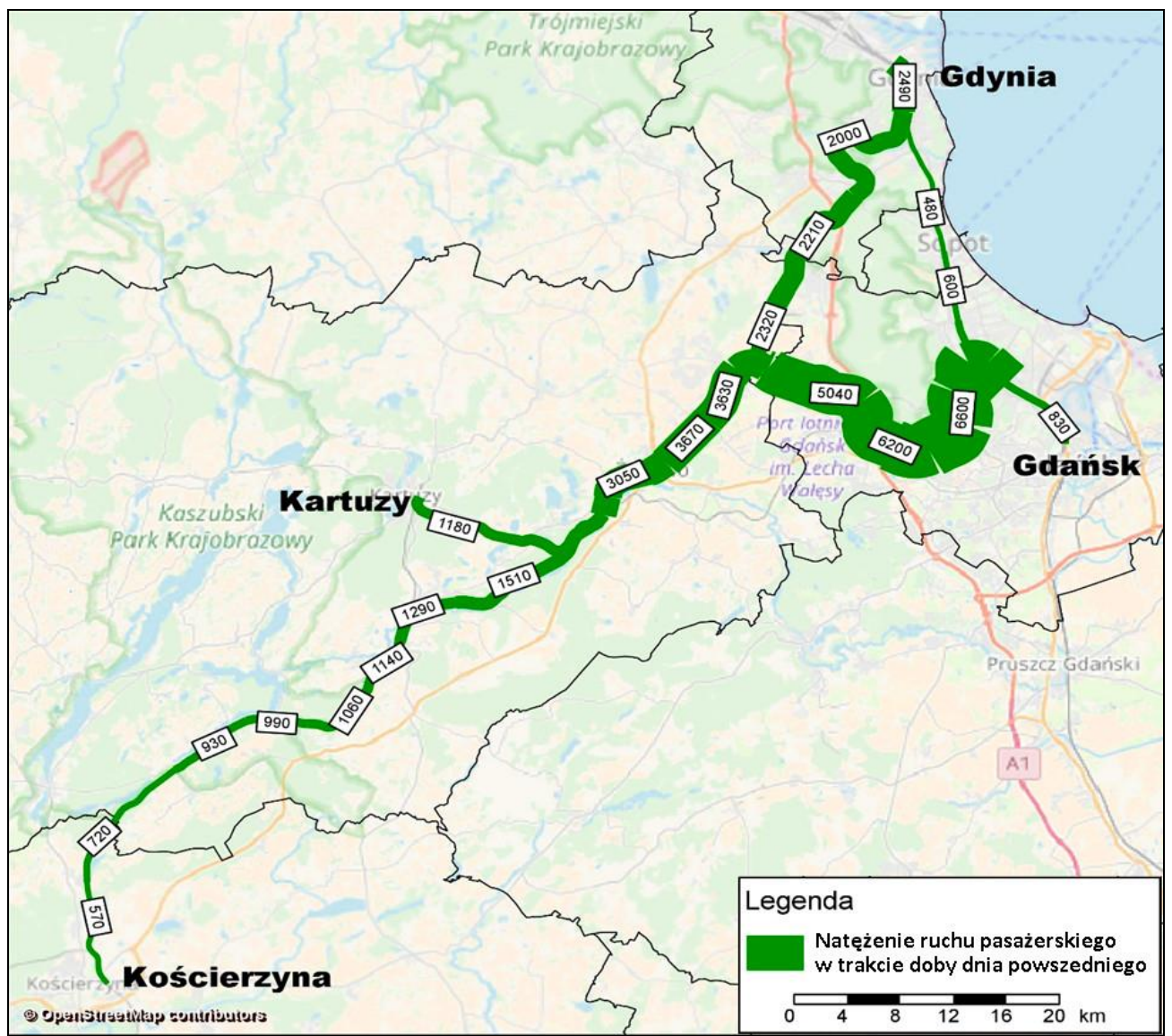

Rys. 5. Natężenie ruchu pasażerskiego w pociagach PKM w dobie dnia powszedniego w 2017 r. [38]

\section{BIBLIOGRAFIA}

1. Bieda K., Kolej aglomeracyjna - nowy czynnik w rozwoju przestrzennym Krakowa, "Czasopismo Techniczne. Architektura”, 2010, nr 1-A, zeszyt 3, rok 107, s. 183-195.

2. Bocheński T., Kolej regionalna na Pomorzu Gdańskim - stan $i$ perspektywy rozwoju, [w:] M. Połom (red.), Wybrane aspekty funkcjonowania transportu na obszarach nadmorskich, seria: Regiony Nadmorskie 24, Wydawnictwo „Bernardinum”, GdańskPelplin 2016, s. 45-59.

3. Bukowski J., Michalski T., Trasy rowerowe nowym elementem sieci transportowych na obszarach aglomeracji miejskich (na przykładzie Trójmiasta), „Prace Komisji Geografii Komunikacji PTG” 1998, t. IV, s. 143-156.

4. Filar P., Zrównoważony transport, [w:] P. Filar, P. Kubicki (red.), Miasto w działaniu. Zrównoważony rozwój z perspektywy oddolnej, Instytut Obywatelski, Warszawa 2012, s. 113-132.

5. Gawek R., Utracona szansa (1979-1989), [w:] R. Gawek i inni, 75 lat Północnego Okręgu Kolei Państwowych, Północna Dyrekcja Kolei Państwowych, Gdańsk 1996, s. 131-160.

6. Goździewicz J., Szybka Kolej Miejska w Trójmieście 1976-2001, „Świat Kolei” 2001, nr 3, s. 13-14.

7. Kolej Metropolitalna w Trójmieście. Badanie podróży, Instytut Kolejnictwa, Warszawa 2010, http://www.pkm-sa.pl/glowna/wpcontent/uploads/2010/09/RAPORT-Kolej-MetropolitalnaAnaliza-marketingowa-PL-03112010.pdf

8. Kopeć K., Aspekt transportowy w monitoringu jakości usług publicznych na szczeblu lokalnym, „Autobusy - Technika, Eksploatacja, Systemy Transportowe" 2016, nr 12, s. 1799-1804.

9. Kopeć K., Commuting to the stadium PGE Arena Gdańsk - the 2012 UEFA European Football Championship perspective, [w:]
T. Michalski, A. Radchenko (red.), Global, continental, national and regional conditions of local development, Publishing House "ADNDU", Gdańsk-Kharkiv 2012, s. 99-107.

10. Kopeć K., Koncepcje kształtowania systemu transportowego współczesnych metropolii, „Zeszyty Naukowe Uniwersytetu Szczecińskiego. Problemy Transportu i Logistyki" 2012, nr 19, s.101-112.

11. Kopeć K., Koncepcje obsługi komunikacyjnej stadionu PGE Arena Gdańsk - ocena krytyczna, [w:] P. Rosik, R. Wiśniewski (red.), Dostępność i mobilność w przestrzeni, Ministerstwo Rozwoju Regionalnego, Warszawa 2012, s. 237-242.

12. Kopeć K., Kształtowanie systemu transportowego miasta w celu osiagania wysokiej jakości życia mieszkańców, „Autobusy Technika, Eksploatacja, Systemy Transportowe” 2016, nr 12, s. 665-669.

13. Kopeć K., Nowoczesne rozwiązania w kształtowaniu komunikacji na obszarach zurbanizowanych, „Logistyka” 2014, nr 6/2014, DVD nr 3, s. 5667-5672.

14. Kopeć K., Pomorska Kolej Metropolitalna jako element zrównoważonego rozwoju systemu transportowego aglomeracji gdańskiej, „Zeszyty Naukowe Uniwersytetu Szczecińskiego. Problemy Transportu i Logistyki” 2014, nr 28, s. 107-124.

15. Kopeć K., Pomorska Kolej Metropolitalna jako nowy element kształtowania komunikacji w aglomeracji gdańskiej, „Logistyka”, 2015, nr 3, s. 5205-5212.

16. Kopeć K., Przeszłość i przyszłość kolei miejskiej w aglomeracji gdańskiej, [w:] M. Tarkowski, J. Mazurek (red.), Wybrane problemy rozwoju lokalnego w Polsce północnej, seria: Regiony Nadmorskie 18, Wydawnictwo „Bernardinum”, Gdynia-Pelplin 2010, s. 49-64.

17. Kopeć K., Specyfika monitoringu aspektu transportowego w monitoringu jakości usług publicznych na szczeblu lokalnym, 
„Autobusy - Technika, Eksploatacja, Systemy Transportowe” 2017, nr 6, s. 1709-1714.

18. Копечь К., Роль місцевого самоврядування у розвитку міської залізниці в Польщі (на прикладі Гданської агломерації), "Ефективність державного управління" 2011, t. 28, s. 262-271.

19. Копечь К., Роль місцевого самоврядування у створенні системи транспортного обслуговування стадіону "PGE Arena Gdańsk" niдчac ЄBPO 2012, [w:] Модернізація системи державного управління: теорія та практика, t. 1, Львівський регіональний інститут державного управління, Львів 2012, s. 447-451.

20. Koźlak A., Kolej aglomeracyjna jako podstawa systemu komunikacyjnego obszarów metropolitalnych w Polsce, „Studia Ekonomiczne. Zeszyty Naukowe Wydziałowe Uniwersytetu Ekonomicznego w Katowicach" 2013, nr 143, s. 172-185.

21. Koźlak A., Perspektywy włączenia transportu kolejowego w obsługe portów lotniczych w Polsce, "Logistyka” 2011, nr 6, s. 4279-4290.

22. Kulpa T., Kulas S., Popadiak B., Zmiany zachowań komunikacyjnych pasażerów po uruchomieniu Szybkiej Kolei Aglomeracyjnej w Małopolsce, „Transport Miejski i Regionalny” 2017, nr 9, s. 5-10.

23. Mapa przebiegu Pomorskiej Kolei Metropolitalnej, Pomorska Kolej Metropolitalna S.A., Gdańsk 2014, http://www.pkmsa.pl/glowna/wp-content/gallery/cache/1120_320x240_pkmmapa-2014_ok.png

24. Michalski L., Birr K., Problemy planowania rozwoju systemu transportowego w obszarach metropolitalnych - przykład Obszaru Metropolitalnego G-G-S, „Metropolitan Przegląd Naukowy" 2017, nr 2(8), s. 82-90.

25. Paradowska M., Rozwój zrównoważonych systemów transportowych polskich miast i aglomeracji w procesie integracji z Unia Europejska - przykład aglomeracji wrocławskiej, Wydawnictwo Uniwersytetu Opolskiego, Opole 2011.

26. Połom M., Dezintegracja usług komunikacyjnych w aglomeracji gdańskiej, „Metropolitan Przegląd Naukowy” 2017, nr 2(8), s. 70-81.

27. Połom M., European Union funds as a growth stimulant of electromobility on the example of electric public transport in Poland, "Barometr Regionalny, Analizy i Prognozy" 2015, t. 13, nr 3, s. 89-96.

28. Połom M., Koncepcja wzrostu znaczenia elektromobilności w transporcie zbiorowym Trójmiasta, „Zeszyty Naukowe Uniwersytetu Szczecińskiego. Problemy Transportu i Logistyki" 2014, s. 181-193.

29. Połom M., Tarkowski M., Rola Pomorskiej Kolei Metropolitalnej w kształtowaniu struktury przestrzenno-funkcjonalnej Gdańska, „Studia Miejskie” 2018, t. 30.

30. Raczyński J., Giedryś A., Wesołowski J., Łódzka Kolej Aglomeracyjna, „TTS Technika Transportu Szynowego” 2012, nr 10, s. 14-22.

31. Raport PKM. I-IX 2015, Pomorska Kolej Metropolitalna S.A., Gdańsk 2015, http://www.pkm-sa.pl/glowna/wpcontent/uploads/2015/12/Raport-PKM_nr-4.pdf

32. Tarkowski M., 2016, Mobilność miejska jako wyzwanie strategicznego programowania rozwoju lokalnego - przykład Gdańska, „Prace Komisji Geografii Komunikacji PTG”, nr 19(4), s. 718.

33. Wesołowski J., Transport Miejski. Ewolucja i problemy współczesne, Politechnika Łódzka, Łódź 2003.

34. Wielobranżowa koncepcja programowo-przestrzenna. Pomorska Kolej Metropolitalna. Etap I - rewitalizacja „Kolei Kokosz- kowskiej”. Faza II - realizacja przedsięwzięcia. Studium Wykonalności, 2012, $\quad$ http://www.pkm-sa.pl/glowna/wpcontent/uploads/2010/09/DSC-Aktualizacja-StudiumWykonalno\%C5\%9Bci-06.03.2012.pdf

35. Wocial M., Rokicki T., Znaczenie zbiorowego transportu szynowego na przykładzie Szybkiej Kolei Miejskiej w aglomeracji warszawskiej, „TTS Technika Transportu Szynowego” 2015, nr 6, s. 19-24.

36. Wojtowicz A., Wojtowicz B., Nessel M., Wykorzystanie narzędzi psychologicznych do pomiaru poziomu jakości życia mieszkańców terenów zurbanizowanych, „Studia i Materiały. Miscellanea Oeconomicae" 2017, Rok 21, Nr 3/2017, tom I, s. 321-332.

37. Wróblewski P., Historia i dzień dzisiejszy Szybkiej Kolei Miejskiej w Trójmieście, 2001, http://www.skm.pkp.pl/o-nas/naszahistorial

38. Wyniki pomiarów natężenia ruchu pasażerskiego na liniach kolejowych obsługiwanych przez PKP SKM Trójmiasto Sp. z 0.0. oraz badań preferencji i zachowań transportowych podróżnych, Pomorskie Biuro Planowania Regionalnego, Gdańsk 2018,

https://pomorskie.eu/documents/39036/1808735/Pomiar+ruchu +SKM/5223ffb6-64cf-4244-92f2-4586805ec895

\section{Pomeranian Metropolitan Railways - the functioning and directions of development}

The article presents the current functioning of the Pomeranian Metropolitan Railway. Significant achievements were identified - especially the large number of passengers in regional connections - with Kartuzy and Kościerzyna, as well as a systematic increase in the number of passengers in all destinations. Failures were also pointed out - above all, an unsatisfactory number of passengers in metropolitan connections. This largely results from a low frequency of trains, maladjustment of the public city transport to the Metropolitan Railway stations and weak connections with trains of the Fast Urban Railway at railway stations in Gdynia Gtówna and Gdańsk Wrzeszcz. Yet, the Pomeranian Metropolitan Railway is developing - the main example being the launch of new stops, Gdynia Karwiny and Gdynia Stadion, on 10 December 2017. Further investments are being plannedincluding, first of all, construction of a new stop Gdańsk Firoga, electrification of the Pomeranian Metropolitan Railway and modernization of railway line No. 201, whose section between Gdynia Glówna and Kościerzyna constitutes part of the Pomeranian Metropolitan Railway. On the other hand, apart from overcoming the mentioned shortcomings which have appeared during the functioning to date, the directions of the development of the Pomeranian Metropolitan Railway should primarily be the extension of the line from Kartuzy to Sierakowice and the construction of a platform for the Pomeranian Metropolitan Railway along with the existing platform for the Fast Urban Railway in Gdynia Wzgórze Śs. Maksymiliana.

\section{Autor:}

mgr Krzysztof Kopeć - Uniwersytet Gdański, Wydział Oceanografii i Geografii, Instytut Geografii, Katedra Geografii Rozwoju Regionalnego, krzysztof.kopec@ug.edu.pl

JEL: L92 DOI: 10.24136/atest.2018.254

Data zgłoszenia: 2018.05.29 Data akceptacji: 2018.06.15 